\title{
Assessment of the Impact of Irrigation with Low- quality Mine Water on Virgin and Rehabilitated Soils in the Upper Olifants Basin
}

\author{
O. A. Idowu ${ }^{1}$, S. A. Lorentz ${ }^{2}$, J. G. Annandale ${ }^{3}$, M. P. McCartney ${ }^{4}$ and \\ N. Z. Jovanovic ${ }^{5}$
}

(1) Department of Water Resources Management and Agrometeorology, University of Agriculture, Abeokuta, Nigeria

(2) School of Bioresources, Engineering and Environmental Hydrology, University of KwaZulu-Natal, Pietermaritzburg, South Africa

(3) Department of Plant Production and Soil Science, University of Pretoria, Pretoria, 002, South Africa

(4) International Water Management Institute Sub-regional Office, P.O. Box 5689, Addis Ababa, Ethiopia

(5) Department of Earth Sciences, University of Western Cape, Bellville, South Africa

O. A. Idowu

Email: olufemidowu@gmail.com

\section{Abstract}

Low-quality mine water from collieries may be used in large quantities to irrigate agricultural crops on virgin (unmined) and rehabilitated soils in South Africa. Such a use could enhance crop production and allow environmentally sustainable mine water disposal. In this study, the volume and qualities of the runoff from two centre pivots irrigated with moderately saline mine water, as well as their soil water salinities, were monitored and used to determine water and salt balances, using the modified ACRU agrohydrological model, ACRU2000, and its salinity module, ACRUSalinity. At both sites, much of the water evaporated, while a significant part of the salt input either precipitated or remained with the water in the soil horizons. A higher percentage of drainage water (and salinity) were retained as ground water storage and a lower percentage of runoff occurred in the rehabilitated sandy loam soil, while a higher percentage of salts accompanied runoff in the virgin clayey soils. Simulated salt saturation values indicate that many crops could be successfully irrigated at $100 \%$ yield potential at either site. Electrical resistivity surveys were carried out at both sites. A general decrease in resistivities with depth in both the virgin and rehabilitated soils reflected the decreasing influence of the mine water used for irrigation with depth and the precipitation of salts in the soils close to the ground surface. The occurrence of a thicker, low-resistivity, near-surface layer near the exit of each pivot area indicates that the water 
and salt content of the subsurface increased in the direction that the surface and nearsurface irrigation water flowed.

\section{Introduction}

The generation of large quantities of mine wastewater in South African collieries and the need for cost effective and environmentally sustainable mine water disposal have generated interest in the possible use of mine water for irrigation. Such a possibility will not only provide a cost-effective method of minimizing excess mine drainage, but will also stabilize dry-land crop production by enhancing dry season farming. Considering that South Africa is predominantly semi-arid with low and variable rainfall (Department of Water Affairs 2002), the use of mine water for irrigation will also boost the beneficial exploitation of the available water resources and relieve the increasing pressure on and competition for the dwindling good quality water by the various sectors of the economy. The Mpumalanga highveld is one of the most important fertile and important agricultural areas in South Africa. About $84 \%$ of the collieries in South Africa are located there (Kenny 2006) and Grobbelaar et al. (2004) estimated that $360 \mathrm{ml} \mathrm{day}^{-1}$ of mine water may be generated after the closure of these mines. In the Olifants basin, part of which lies in the Mpumalanga Province (Fig. 1), they estimated that a volume of $17 \mathrm{ml} \mathrm{day}^{-1}$ may be generated. Considering the availability of fertile land and large quantities of mine water, as well as the current implementation of best practises in the rehabilitation of mines by collieries (Limpitlaw et al. 2005), a large amount of mine water could be used for irrigation on virgin and rehabilitated soils in Mpumalanga. 


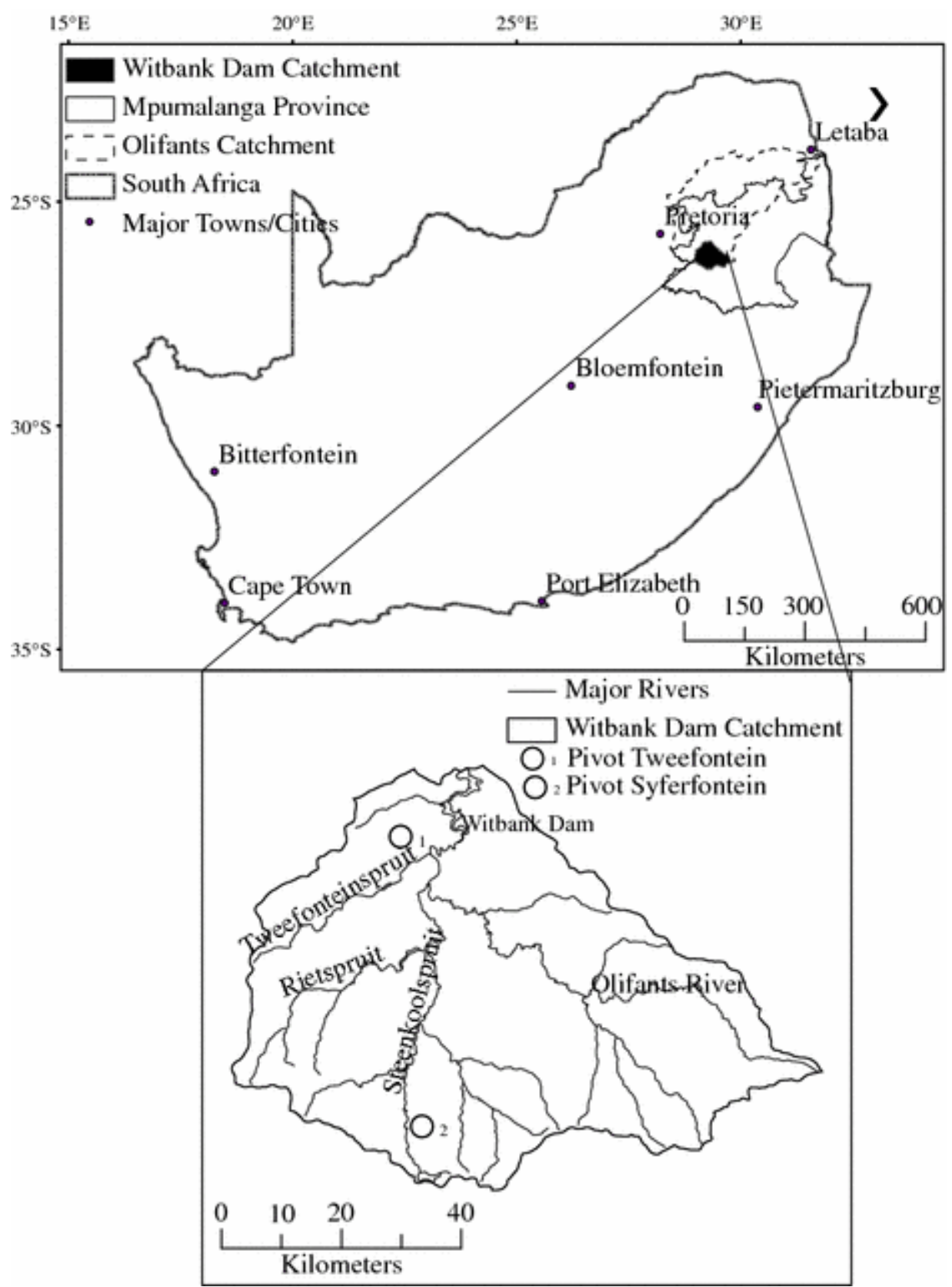

Fig. 1 Study area

The use of low-quality South African mine water for irrigation has been investigated in quite some detail (Barnard et al. 1998; Du Plessis 1983; Jovanovic 1998) and there have been field trials on several centre pivots irrigated with gypsiferous mine water in the Mpumalanga coalfields (Annandale 2001, 2002; Annandale et al. 2006; Beletse 2004; Jovanovic et al. 2002). These studies indicated that with adequate land preparation and fertilisation management, several crops and pasture, including maize, wheat, sugar beans, lucerne, and fescue (cv. Demeter), could be successfully irrigated with low-quality mine water. No foliar injury was observed in the crops. The soil salinity in the centre pivots increased over the duration of the trials, due mainly to increases in the concentrations of 
$\mathrm{Ca}^{2+}, \mathrm{Mg}^{2+}$, and $\mathrm{SO}_{4}$, which were the main ionic species in the irrigation water. The saturated soil electrical conductivity (EC) and drainage water quality varied, depending on rainfall. Long-term simulation of irrigation with gypsiferous mine water for 30 years, followed by 20 years of dry land cropping on virgin soil using a mechanistic soil watersalt balance generic crop growth model, SWB (Annandale et al. 1999a), indicated that the soil acted as an effective salt sink, with large quantities (340-404 $\mathrm{Mg} \mathrm{ha}^{-1}$ ) of calcium sulphate precipitated in 30 years, and with negligible amounts of remobilization thereafter (Annandale et al. 1999b). Most salts precipitated in winter and most leaching occurred in summer. Depending on irrigation strategy, between 418 and $636 \mathrm{Mg} \mathrm{ha}^{-1}$ of salts was leached over 30 years. Very little leaching occurred after the irrigation ceased. High frequency irrigation, with a leaching fraction in winter, was found to be an effective and economical means of disposing of large quantities of salt and water without causing irreparable damage to soil resources.

In this study, we assessed the impact of using low-quality mine water for irrigation on two centre pivots irrigating virgin and rehabilitated soils in parts of the Upper Olifants basin in the Mpumalanga Province (Fig. 1). The ACRU agrohydrological model (Schulze 1995) in the form of ACRU2000 and its salinity module, ACRUSalinity, along with a 2-D electrical resistivity survey were used to understand the distribution of water and salts, and the impact that this distribution had on the water quality of both runoff and ground water in the two land use types. Unlike other studies, each of the centre pivots was treated as part of a hydrological system, with due consideration given to the runoff from the pivots, thereby adequately accounting for all the important components of the simulated hydrologic system, viz. ground water storage, evapotranspiration, baseflow, interception, irrigation water supply, and rainfall. The 2-D resistivity survey was complementary to the simulation of the centre pivots for water and salt balances computation in determining and comparing the subsurface resistivity distribution that might arise from irrigation with low-quality mine water at the two land use types under consideration.

\section{The ACRU Agrohydrological Model}

The ACRU agrohydrological model is a multi-purpose, daily time step, physical conceptual model that integrates the various water budgeting and runoff-producing components of the terrestrial hydrological system (Schulze et al. 1995). It is structured to be highly sensitive to land cover/use and climate changes and its water budgeting is responsive to supplementary watering by irrigation, inflows, and abstractions. The model can operate either as a lumped small catchment model or as a distributed cell-type model for larger catchments or in areas of complex land use and soils. Water input into the hydrologic system occurs as precipitation or irrigation. In reservoirs, inflows and abstractions can take place. Vegetative or impervious (and impermeable) land covers may intercept part or all of the water input. Rainfall and/or irrigation water not abstracted as interception or as storm flow (either rapid response or delayed) first enters and resides in the topsoil (A) horizon. When the drained upper limit of the topsoil is reached, excess water percolates into the subsoil (B) horizon as saturated drainage at a rate dependent on respective horizon soil textural characteristics, wetness, and other drainage-related properties. Saturated and unsaturated soil water redistribution may take place between 
soil horizons. Soil water that moves downwards from the lower (B) soil horizon drains into ground water storage, from where baseflow may be generated.

In an irrigated area, soil water redistribution takes place in only one soil horizon, the tilled soil layer, which is the zone in which the majority of roots occur, and therefore, where the amount of water available in the soil is regulated (Lecler and Schulze 1995). Due to repeated tillage, this zone is assumed to be homogenous, so that differentiation into horizons A and B is considered unnecessary. The depth of this zone can be stipulated by the ACRU user.

Evaporation takes place from the intercepted water and from the various soil horizons; in the latter case, it can be split into separate components of soil water evaporation and plant transpiration, or combined as total evaporation. Plant transpiration takes place from all root-active soil horizons. We employed ACRU2000 in this study, which is the objectoriented version of the ACRU agrohydrological model and is written in Java programming language (Clark et al. 2001).

ACRUSalinity is the hydrosalinity module of ACRU2000 and inherits the basic structures and flow configuration of ACRU2000 (Teweldebrhan et al. 2003). The internal computations of the hydrosalinity processes in ACRUSalinity involve salt load ( $\mathrm{mg}$ ) in terms of total dissolved solids (TDS). ACRUSalinity thus determines the conservative salt load in different components of a hydrologic system but not the different solute species concentrations. The salt load of the subsurface layers is replenished from internal and external sources. The salt load of the A horizon is replenished from rainfall salt input and irrigation water, whereas, in the B horizon and ground water storage, it is replenished by the salt load added from an overlying layer along with the percolating water. The internal source of salt load to a particular soil horizon or ground water storage is through salt dissolution from the soil horizon and the aquifer in which the ground water is stored. The salt generating process is based on the first order rate kinetics proposed by Ferguson et al. (1994). If the salinity of a soil layer is greater than the specified maximum concentration, then the excess salt load is precipitated. ACRUSalinity therefore enables the assessment of the salt load transport in subsurface components and runoff, as well as the allocation of the runoff salt load to various destination components within a land segment area. It can therefore deal with salt load transport in dry land and irrigated conditions, in reservoirs and channel reaches, and for upward and downward subsurface salt.

Recently, the original assumption in ACRUSalinity that the storm flow has the same salinity as the rainfall was realized to be inaccurate (Idowu 2007; Thornton-Dibb et al. 2005). Storm flow salinity can vary significantly from rainfall salinity, especially after periods of no rainfall, when the salinity in the soil, mainly near the surface, can increase due to evaporation. When a rainfall event occurs, overland flow comes in contact with the accumulated salts near the surface of the soil and results in a net increase in the salinity of the storm flow relative to rainfall. In order to account for this, a soil surface layer has been added to ACRUSalinity. The soil surface layer is conceptualised as a thin soil layer that will drain quickly into the A-Horizon (unless the A-Horizon is already wet) and its addition is meant to model the process of storm flow water picking up salts accumulated 
near the surface of the soil. Salt dissolution, and the resulting storm flow salinity during rainfall, is based on a simplified empirical model developed by Sharpley et al. (1981) to describe desorption of phosphorous $(\mathrm{P})$ from agricultural soil to rainfall and runoff. The salt load associated with the intercepted rainfall contributes to the system and is therefore added to the surface layer. This is based on the assumption that the salt load that is deposited on the vegetation as a result of interception is washed down the branches and stems onto the soil surface layer in a subsequent rainfall.

\section{Materials and Methods}

Two sites, each equipped with a centre pivot, were chosen for this study. The first, pivot Tweefontein, is located in the Kleinkopje Colliery (Anglo Coal, Witbank, Mpumalanga Province, South Africa) and irrigated 20 ha of rehabilitated soil. The irrigated area has a topsoil of sandy loam of an average thickness of $0.93 \mathrm{~m}$ overlying coal spoils. The second, pivot Syferfontein, is located at Syferfontein (SASOL, Secunda, Mpumalanga Province, South Africa) and irrigated 21 ha of virgin clayey soils. The characteristics of pivots Syferfontein and Tweefontein and their soil water retention characteristics at a depth of $0.1 \mathrm{~m}$ are presented in Table 1 and Fig. 2, respectively.

Table 1 Characteristics of the irrigated areas

\begin{tabular}{|l|l|l|}
\hline Parameters & Virgin & Rehabilitated \\
\hline Name & Pivot Syferfontein & Pivot Tweefontein \\
\hline Locations & $29^{\circ} 20^{\prime} \mathrm{E}, 23^{\circ} 64^{\prime} \mathrm{S}$ & $29^{\circ} 12^{\prime} \mathrm{E}, 26^{\circ} 00^{\prime} \mathrm{S}$ \\
\hline Elevation $(\mathrm{m})$ & 1,610 & 1,570 \\
\hline Irrigated area (ha) & 21 & 20 \\
\hline Soil type & Clay & Sandy loam \\
\hline Wilting point & 0.3 & 0.093 \\
\hline Drained upper limit & 0.43 & 0.2 \\
\hline Porosity & 0.48 & 0.448 \\
\hline Crop & Pasture & Maize \\
\hline Maximum rooting depth $(\mathrm{m})$ & 1.2 & 2 \\
\hline Zone of major water uptake $(\mathrm{m})$ & 0.6 & 1 \\
\hline
\end{tabular}



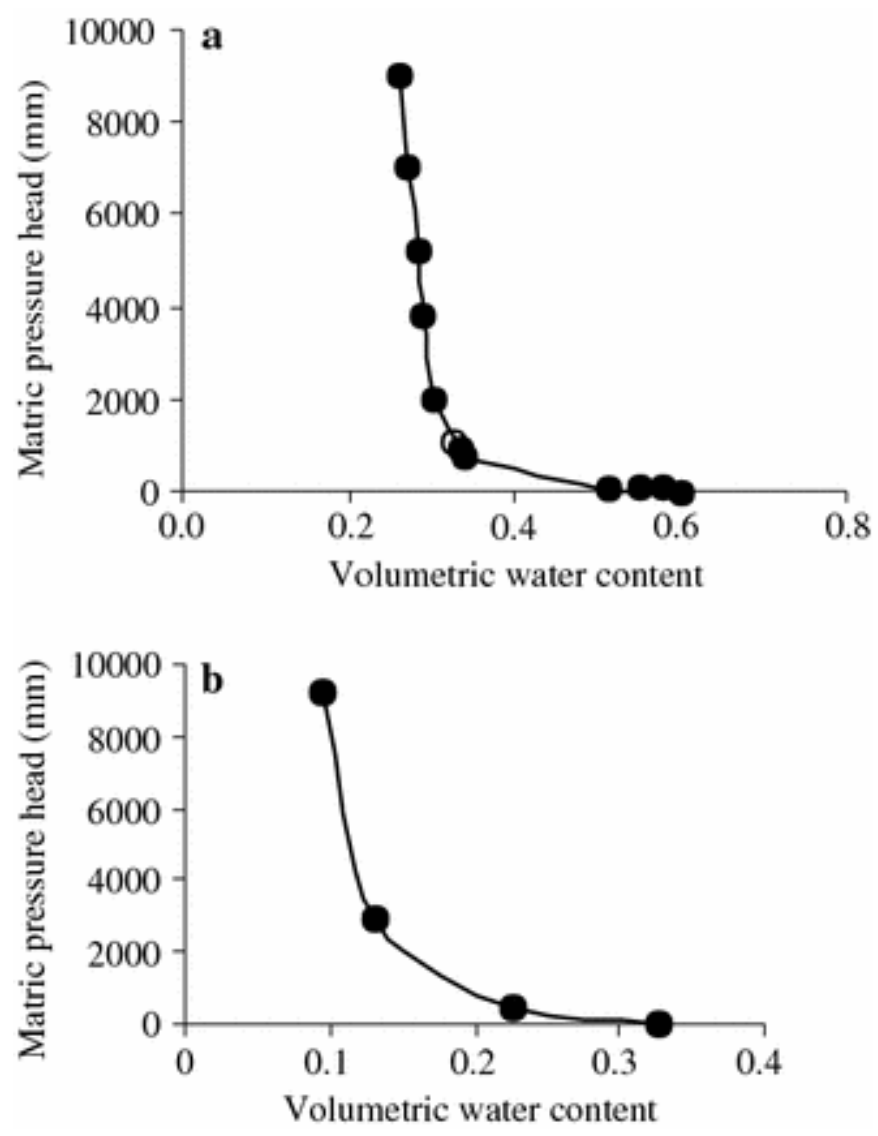

Fig. 2 Soil water retention characteristics for pivots Syferfontein (a) and Tweefontein (b) at a depth of $0.1 \mathrm{~m}$

The irrigation water was abstracted from surface reservoirs, which acted as storage and evaporation pans for the water pumped from opencast pits. The water is highly mineralized and hence of low quality, a condition which makes direct discharge to the river system unsuitable, except in periods of high rainfall when there is adequate dilution capacity and controlled release is allowed by the regulating authority. The typical qualities of the applied irrigation water during the monitoring period are shown in Table 2. With the EC lying between 200 and $1,000 \mathrm{mS} / \mathrm{m}$ (i.e. $2-10 \mathrm{dS} / \mathrm{m}$ ), the irrigation water was moderately saline (Rhoades et al. 1992) due to the presence of $\mathrm{SO}_{4}{ }^{2-}, \mathrm{Na}^{+}$(for Syferfontein) and $\mathrm{Ca}^{+}$(for Tweefontein). With a sodium adsorption ratio (SAR) of 14, the applied irrigation water at Syferfontein was sodic (Pearson 2003). 
Table 2 Typical irrigation water qualities

\begin{tabular}{|l|l|l|}
\hline Chemical properties & Syferfontein & Tweefontein \\
\hline $\mathrm{pH}$ & 9.1 & 8 \\
\hline $\mathrm{EC}(\mathrm{mS} / \mathrm{m})$ & 380 & 300 \\
\hline $\mathrm{Ca}^{2+}(\mathrm{mg} / \mathrm{l})$ & 30 & 420 \\
\hline $\mathrm{Mg}^{2+}(\mathrm{mg} / \mathrm{l})$ & 80 & 240 \\
\hline $\mathrm{Na}^{+}(\mathrm{mg} / \mathrm{l})$ & 630 & 32 \\
\hline $\mathrm{Cl}^{-}(\mathrm{mg} / \mathrm{l})$ & 40 & 8.2 \\
\hline $\mathrm{SO}_{4}{ }^{2-}(\mathrm{mg} / \mathrm{l})$ & 1,660 & 1,750 \\
\hline $\mathrm{SAR}(\mathrm{me} / \mathrm{l})$ & 14 & 0.3 \\
\hline
\end{tabular}

SAR sodium adsorption ratio

The pivots were equipped with automatic weather stations to monitor the weather conditions (rainfall, temperature, relative humidity, solar radiation, and wind speed) and tipping buckets rain gauges, which measured the amount and intensity of rainfall and irrigation. Ceramic cup soil water samplers were installed within the centre pivots (at depths of $0.4,1$, and $1.4 \mathrm{~m}$ ) for determining the soil water salinity. In order to facilitate adequate drainage and monitoring of the runoff from the pivots, waterways were constructed so that runoff could leave the pivots over a weir (flume, in the case of pivot Syferfontein) where the quantity and quality of runoff were monitored, using Campbell logger CR10X and ISCO 3700 portable samplers. The loggers were programmed to determine the height of water above the weir/flume every second and convert the height to flow using the appropriate algorithms and dimensions of the weir/flume. The average height of water above the weir/flume and the flow rate every 2 min were determined and stored along with the day, date, time, and voltage of the battery. Each of the loggers was set up to signal the ISCO sampler when the volume of flow totaled $25 \mathrm{~m}^{3}$ to collect a sample of $450 \mathrm{ml}$, and then reset itself to sample again when the volume of flow amounted to $25 \mathrm{~m}^{3}$. Based on experience with the volume of runoff from the pivot, the sampling volume interval of $25 \mathrm{~m}^{3}$ was adequate for monitoring the quantity and quality of the runoff from the pivot. The bottle number, day, date, and time of sampling were stored by the data logger. Data was downloaded from the logger and water samples were collected from the ISCO sampler fortnightly. The water samples were sent to the laboratory for chemical analysis. The monitoring at the two pivots lasted for about one year.

The 2-D electrical resistivity survey was carried out with an ABEM SAS 1000 Terrameter, an ES 464 switching unit, four multicore cables, and 25 stainless steel pegs. Two surveys were performed at each of the centre pivots, the first with an electrode separation of $2.5 \mathrm{~m}$ and the second with a spacing of $5 \mathrm{~m}$, using the "roll-along" surveying method and the Wenner array configuration. In order to account for variation in resistivities in the vertical as well as the horizontal directions, 2-D model interpretations of the apparent resistivities obtained from the electrical resistivity survey were carried out using the RES2-DINV program, which uses the smoothness-constrained 
least-squares inversion technique to determine the appropriate resistivity of the subsurface (Loke 2000, 2004). The 2-D model interpretations are presented in pseudosections, which showed the resistivity changes of the subsurface in the vertical as well as horizontal directions along the survey line.

In employing ACRU2000 and ACRUSalinity in this study, the irrigated pivots were made to be parts of land segments that were a little bigger than the pivots because, in ACRU2000, an irrigated field is conceptualised as part of a bigger land segment, and so could not be simulated alone. However, water and salt balances results could be output separately for the irrigated centre pivots. Pivot Syferfontein was planted to pasture, while Tweefontein was planted to maize during the monitoring period. The TDS of the rainfall is required as input into ACRUSalinity. A value of $4 \mathrm{mS} / \mathrm{m}(26 \mathrm{mg} / \mathrm{l})$ was used. The value was based on the average EC of rainfall in the Johannesburg area (Blight 1992). Considering that air pollutants disperse quickly on the Transvaal Highveld, this value may not be significantly different from that of the study area. The salinity obtained from the ceramic cup water samplers at a date close to the starting date of simulation was used as the initial value. Continuous data could not be obtained from the ceramic cup water samplers due to difficulties encountered in extracting soil water from them, particularly under dry conditions. The simulated results were verified using the observed runoff volume and salinity from the irrigated areas. The simulated results formed the basis of the analyses of the total water and salt balances of the two irrigated pivots.

\section{Results and Discussion}

\section{Water and Salt Balances}

The observed and simulated volume of runoff from pivots Syferfontein and Tweefontein are presented in Figs. 3 and 4, respectively, while comparisons of the salinities of the observed and simulated runoffs are presented in Figs. 5 and 6. The observed runoff records were not continuous due to logistic problems associated with the downloading of data from the data loggers and the collection of water samples from the ISCO samplers. Inability to collect all the water samples from the ISCO samplers immediately after they were filled with water meant that flows could pass unsampled. Similarly, once the storage capacity of the data logger was full, the earlier collected data was overwritten, thereby making the retrieval of such data impossible. Nevertheless, a correlation coefficient of 0.5 and 0.9 between the simulated and observed runoff volume and salinities respectively indicated that the simulated runoff volume and salinities mimicked the observed reasonably well. The water and salt balances obtained from the simulated results are presented in Tables 3, 4, 5, and 6 . 


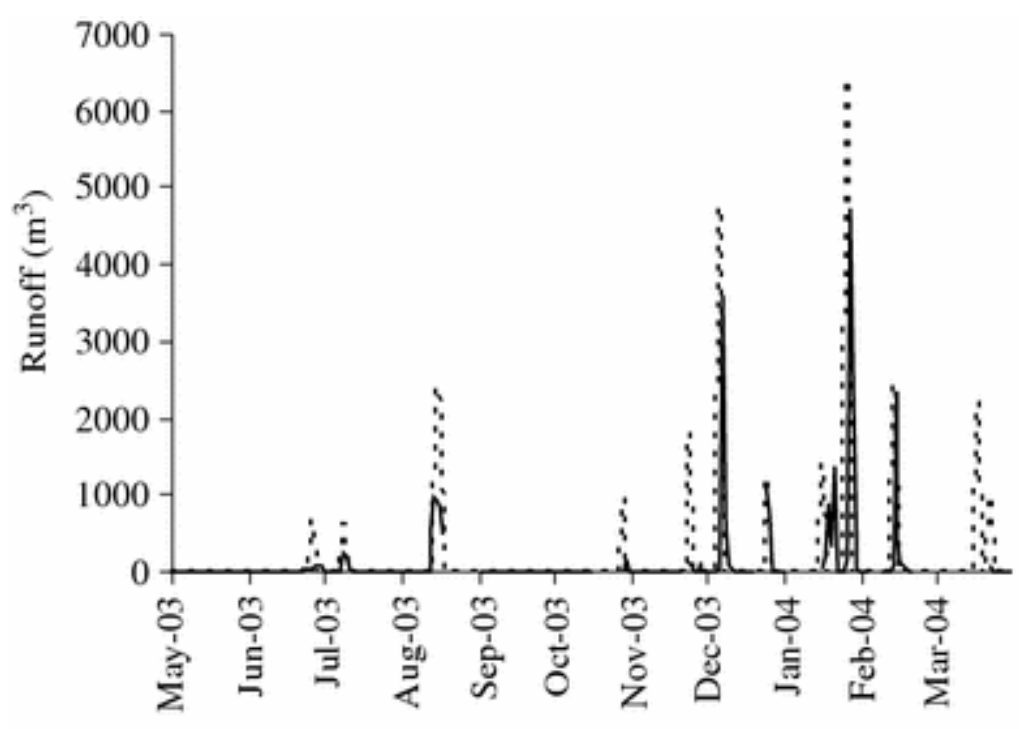

Observed $\cdots \cdot$. Simulated

Fig. 3 Observed and simulated runoff from Syferfontein

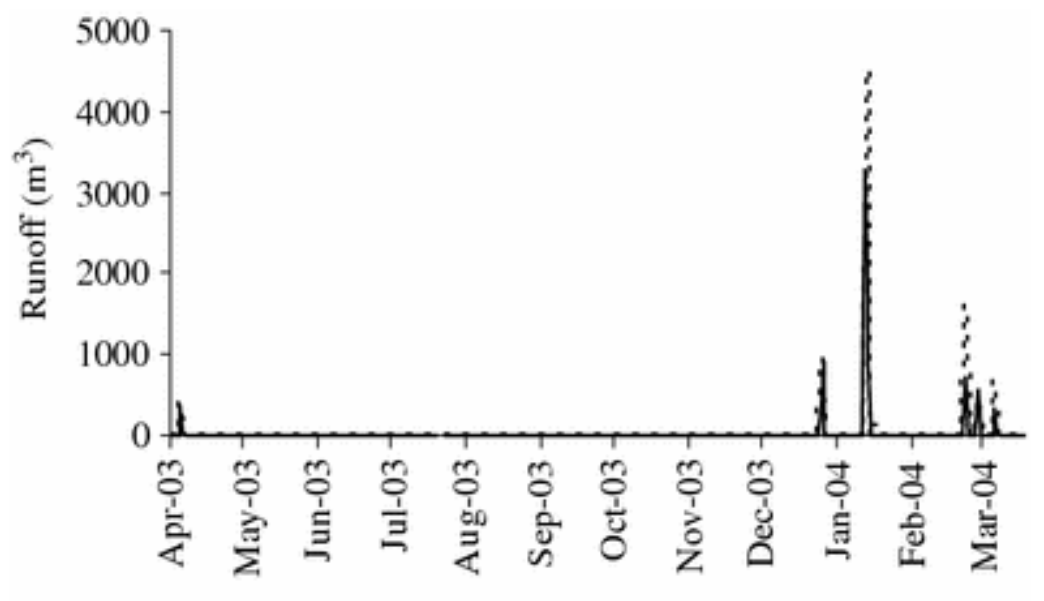

Observed $\cdots \cdots$ simulated

Fig. 4 Observed and simulated runoff from Tweefontein 


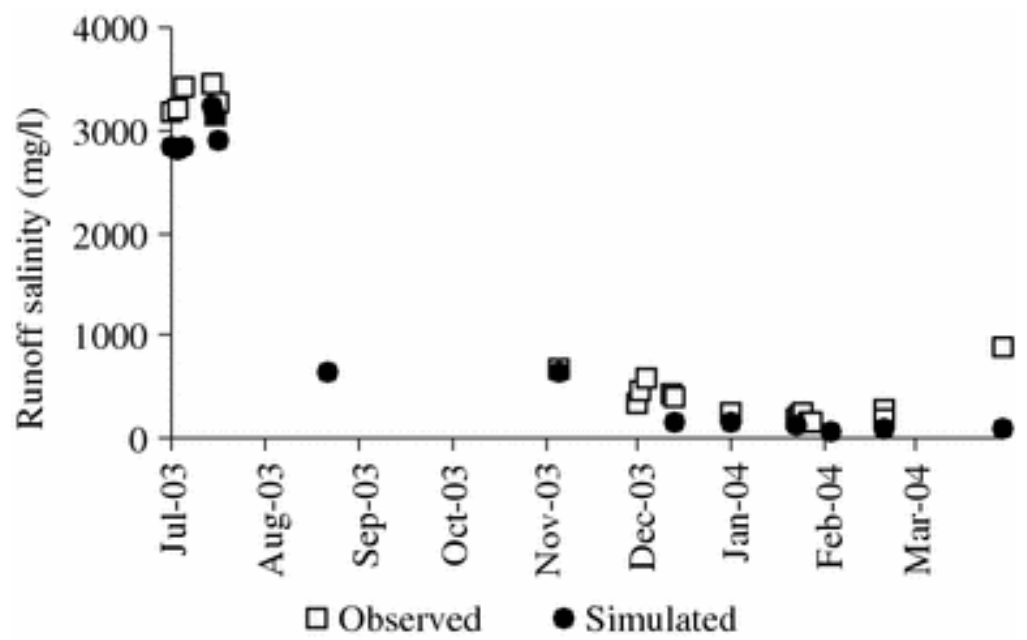

Fig. 5 Observed and simulated runoff salinities from Syferfontein

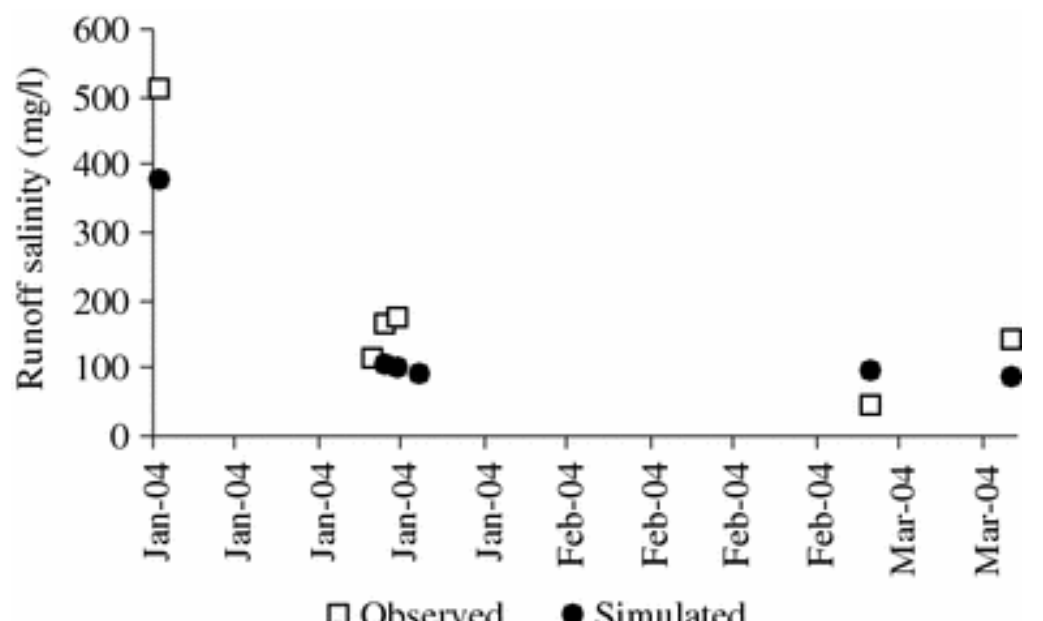

Fig. 6 Observed and simulated runoff salinities from Tweefontein

Table 3 Water balance of Syferfontein pivot

\begin{tabular}{|c|c|c|c|c|c|c|c|}
\hline \multirow[b]{2}{*}{ Items } & \multicolumn{2}{|c|}{ Supplied water } & \multicolumn{5}{|c|}{ Water distribution } \\
\hline & Rainfall & $\begin{array}{l}\text { Irriga- } \\
\text { tion }\end{array}$ & Runoff & $\begin{array}{l}\text { Total } \\
\text { evapo- } \\
\text { ration }\end{array}$ & $\begin{array}{l}\text { Soil } \\
\text { moisture }\end{array}$ & $\begin{array}{l}\text { Drainage } \\
\text { to ground } \\
\text { water }\end{array}$ & $\begin{array}{l}\text { Interception } \\
\text { loss }\end{array}$ \\
\hline Volume $\left(\mathrm{m}^{3}\right)$ & 83,559 & 135,660 & 28,160 & 165,819 & 109.87 & 5,397 & 18,524 \\
\hline Depth (mm) & 397.9 & 646 & 134.1 & 789.6 & 0.52 & 25.7 & 88 \\
\hline $\begin{array}{l}\text { Total available } \\
\text { water }(\%)\end{array}$ & 38 & 62 & 13 & 76 & 0.05 & 2.5 & 8.45 \\
\hline
\end{tabular}


Table 4 Water balance of Tweefontein pivot

\begin{tabular}{|c|c|c|c|c|c|c|c|}
\hline \multirow[b]{2}{*}{ Items } & \multicolumn{2}{|c|}{ Supplied water } & \multicolumn{5}{|c|}{ Water distribution } \\
\hline & Rainfall & Irrigation & Runoff & $\begin{array}{l}\text { Total } \\
\text { evaporation }\end{array}$ & $\begin{array}{l}\text { Soil } \\
\text { moisture }\end{array}$ & $\begin{array}{l}\text { Drainage } \\
\text { to ground } \\
\text { water }\end{array}$ & $\begin{array}{l}\text { Interception } \\
\text { loss }\end{array}$ \\
\hline $\begin{array}{l}\text { Volume } \\
\left(\mathrm{m}^{3}\right)\end{array}$ & 125,100 & 61,130 & $8,879.04$ & $141,594.46$ & 23,218 & $6,097.8$ & 7,616 \\
\hline $\begin{array}{l}\text { Depth } \\
(\mathrm{mm})\end{array}$ & 625.5 & 305.65 & 44.40 & 707.97 & 116.09 & 30.49 & 38.08 \\
\hline $\begin{array}{l}\text { Total } \\
\text { available } \\
\text { water (\%) }\end{array}$ & 67 & 33 & 5 & 76 & 12 & 3 & 4 \\
\hline
\end{tabular}

Table 5 Salt balance of Syferfontein pivot

\begin{tabular}{|c|c|c|c|c|c|c|c|c|c|}
\hline \multirow{3}{*}{ Items } & \multicolumn{2}{|c|}{ Supplied salts } & \multirow{3}{*}{$\begin{array}{l}\text { Gene- } \\
\text { rated } \\
\text { salts }\end{array}$} & \multirow{3}{*}{\begin{tabular}{|l|}
$\begin{array}{l}\text { Salt } \\
\text { distri } \\
\text { bu- } \\
\text { tion }\end{array}$ \\
$\begin{array}{l}\text { Run- } \\
\text { off }\end{array}$ \\
\end{tabular}} & & & & & \multirow[b]{3}{*}{$\begin{array}{l}\text { Drainage } \\
\text { to ground } \\
\text { water }\end{array}$} \\
\hline & \multirow[b]{2}{*}{$\begin{array}{l}\text { Rain- } \\
\text { fall }\end{array}$} & \multirow[b]{2}{*}{$\begin{array}{l}\text { Irriga- } \\
\text { tion }\end{array}$} & & & \multicolumn{2}{|l|}{ Topsoil } & \multicolumn{2}{|c|}{ Soil surface layer } & \\
\hline & & & & & $\begin{array}{l}\text { Precipita } \\
\text { ted salts }\end{array}$ & $\begin{array}{l}\text { Dissolved } \\
\text { salts }\end{array}$ & $\begin{array}{l}\text { Precipita } \\
\text { ted salts }\end{array}$ & $\begin{array}{l}\text { Dissol- } \\
\text { ved } \\
\text { salts }\end{array}$ & \\
\hline \begin{tabular}{|l|} 
Mass \\
(tons)
\end{tabular} & 2.17 & 277.02 & 2.19 & 22.48 & 92.24 & 147.21 & 1.84 & 4.07 & 13.52 \\
\hline$\%$ & 0.8 & 99.2 & & 8 & 33 & 52 & 0.6 & 1.4 & 5 \\
\hline
\end{tabular}

Total available salts $=281.38$ tons

Table 6 Salt balance of Tweefontein pivot

\begin{tabular}{|c|c|c|c|c|c|c|c|c|c|}
\hline \multirow{3}{*}{ Items } & \multicolumn{2}{|c|}{$\begin{array}{l}\text { Supplied } \\
\text { salts }\end{array}$} & \multirow{3}{*}{$\begin{array}{l}\text { Genera } \\
\text {-ted } \\
\text { salts }\end{array}$} & \multirow{3}{*}{\begin{tabular}{|l}
$\begin{array}{l}\text { Salt } \\
\text { distri- } \\
\text { bution }\end{array}$ \\
Runoff \\
\end{tabular}} & & & & & \\
\hline & \multirow[b]{2}{*}{$\begin{array}{l}\text { Rain- } \\
\text { fall }\end{array}$} & \multirow[b]{2}{*}{$\begin{array}{l}\text { Irriga } \\
\text {-tion }\end{array}$} & & & \multicolumn{2}{|l|}{ Topsoil } & \multicolumn{2}{|c|}{ Soil surface layer } & \multirow{2}{*}{\begin{tabular}{|l|} 
Drainage \\
to \\
ground \\
water \\
\end{tabular}} \\
\hline & & & & & $\begin{array}{l}\text { Precipita- } \\
\text { ted salts }\end{array}$ & $\begin{array}{l}\text { Dissolved } \\
\text { salts }\end{array}$ & $\begin{array}{l}\text { Precipi- } \\
\text { tated } \\
\text { salts }\end{array}$ & $\begin{array}{l}\text { Dissol- } \\
\text { ved salts }\end{array}$ & \\
\hline $\begin{array}{l}\text { Mass } \\
\text { (tons) }\end{array}$ & 3.25 & $\begin{array}{l}117.3 \\
7\end{array}$ & 0.30 & 1.13 & 59.79 & 37.85 & 0 & -1.35 & 23.25 \\
\hline$\%$ & 3 & 97 & & 1 & 49 & 31 & 0 & 0 & 19 \\
\hline
\end{tabular}

Total available salts $=120.92$ tons 
The total amount of water supplied to pivot Syferfontein from irrigation and rainfall was about $2.19 \times 10^{5} \mathrm{~m}^{3}$, representing $1,043.9 \mathrm{~mm}$ of water. Rainfall and irrigation water constituted about 38\% (398 $\mathrm{mm})$ and 62\% (646 $\mathrm{mm})$, respectively. Most of the water $(76 \%)$ was lost through evapotranspiration, while about $13 \%(136 \mathrm{~mm})$ occurred as runoff. About 3\% (26 mm) went into ground water storage, while the change in soil moisture content of the soil surface layer/topsoil was very small $-0.05 \%$, representing $0.52 \mathrm{~mm}$ of water. Interception loss was about $8 \%$, representing about $88 \mathrm{~mm}$ of water. The total amount of salt from the rainfall and irrigation water supplied onto the pivot was about 229 metric tons $(t)$, with almost all the salts (99\%) coming from irrigation. The relative higher TDS of the irrigation water $(2,042 \mathrm{mg} / \mathrm{l})$ compared to that of the rainfall (26 mg/l), as well as the different volumes (62 and 38\%, respectively), were responsible for the higher contribution of salts from irrigation. The total amount of salts generated, which represented salt uptake from the geology of the rocks was $2.19 \mathrm{t}$, thereby making the total amount of available salts about $218 \mathrm{t}$. The salt load associated with runoff was about $22 \mathrm{t}$, representing about $8 \%$ of the total salts available, while the total amount of salts precipitated in the topsoil horizon was about $92 \mathrm{t}(33 \%)$. Less than $1 \%$ of the total salts $(1.8 \mathrm{t})$ occurred as precipitated salts in the soil surface layer. About $14 \mathrm{t}(2.5 \%) \mathrm{went}$ into ground water storage. The salt loadings associated with the increase in the salinities of the water in the topsoil/soil surface layer were 147 (52\%) and $4 \mathrm{t}(1 \%)$, respectively. Of the total amount of water supplied to the pivot Tweefontein $(931.15 \mathrm{~mm})$, irrigation constituted 33\% (306 mm), while rainfall constituted 67\% (623 mm). As with Syferfontein, most of the water $(708 \mathrm{~mm})$ supplied onto the pivot was lost through evapotranspiration. Runoff was $44 \mathrm{~mm}(5 \%)$ and the amount that drained into ground water storage was $31 \mathrm{~mm}$, representing about $3 \%$. The total amount of salt that accompanied the supplied water was about $121 \mathrm{t}$. Salts from irrigation water constituted $97 \%(117.4 \mathrm{t})$, while that from rainfall was 3\% (3.3 t). The generated salt was $0.3 \mathrm{t}$, making the total available salts about $121 \mathrm{t}$. The amount of salts that accompanied runoff was about $1 \%$ of the total available salt, while $19 \%$ (about $23 \mathrm{t}$ ) accompanied drainage water into ground water storage. About $49 \%$ of the salt, representing about $60 \mathrm{t}$, was precipitated in the top soil horizons, while the salt load associated with the increase in the salinity of water in topsoil was about $31 \%$. Insignificant amount of salts $(21 \mathrm{~g})$ occurred as precipitated salts on the soil surface layer. A net decrease in the salinity of the water in the surface layer occurred from $3,611 \mathrm{mg} / \mathrm{l}$ at the beginning of simulation to about $450 \mathrm{mg} / \mathrm{l}$ at the end of simulation, thereby making the increase in salt load zero.

Water and salt distribution at both Syferfontein and Tweefontein pivots are presented in Figs. 7 and 8. Differences in the characteristics of the water and salt distribution for the two pivots were due to the different soil types and crops planted on the pivots, the differences in the amounts and salt loads of the irrigation water supplied onto the pivots, and the unmined and rehabilitated nature of the irrigated areas. While the soil at the rehabilitated land was sandy, that at the virgin land was clay. Although the porosity and the residual water of the clay at pivot Syferfontein were relatively higher than that of the sandy loam in pivot Tweefontein ( 0.8 and 0.25 against 0.3 and 0.09 , respectively, Fig. 2 ), in general, clay is relatively impermeable and drains poorly. These are reflected in the higher percentage of the volume of water that occurred as runoff of the total available water in Syferfontein. As a result of the higher percentage of runoff in Syferfontein, the 
percentage of the volume of water that percolated into ground water storage was lower than at pivot Tweefontein (Fig. 7). Unlike Tweefontein, salt precipitation and increase in the soil water salinity occurred in the soil surface layer at Syferfontein. This may have been caused by water logging (ponding) and eventual evaporation (with the deposition of the salts) due to the clayey nature of the soil at Syferfontein, coupled with the fact that more saline irrigation water than rainfall was used at Syferfontein. Although ponding of water also occurred at Tweefontein due to subsidence, irrigation water played a greater role in the water logging at Syferfontein where the water and salt inputs from irrigation clearly exceeded that from rainfall, whereas at Tweefontein, the amount of rainfall was more than double that of irrigation water.

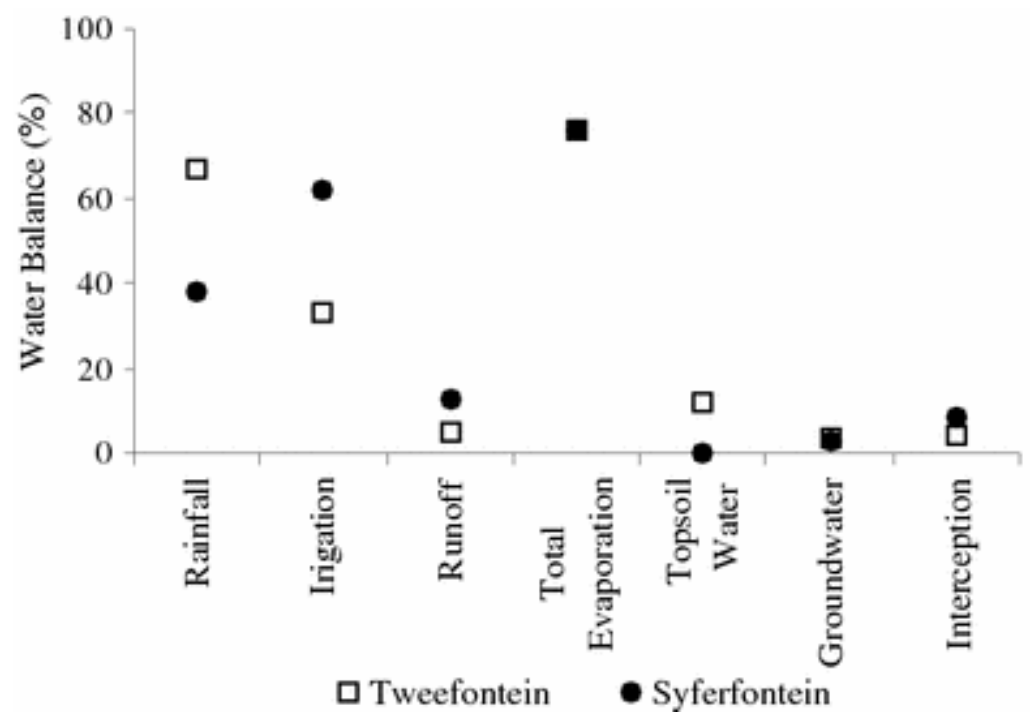

Fig. 7 Comparison of pivots Tweefontein and Syferfontein supplied water distribution

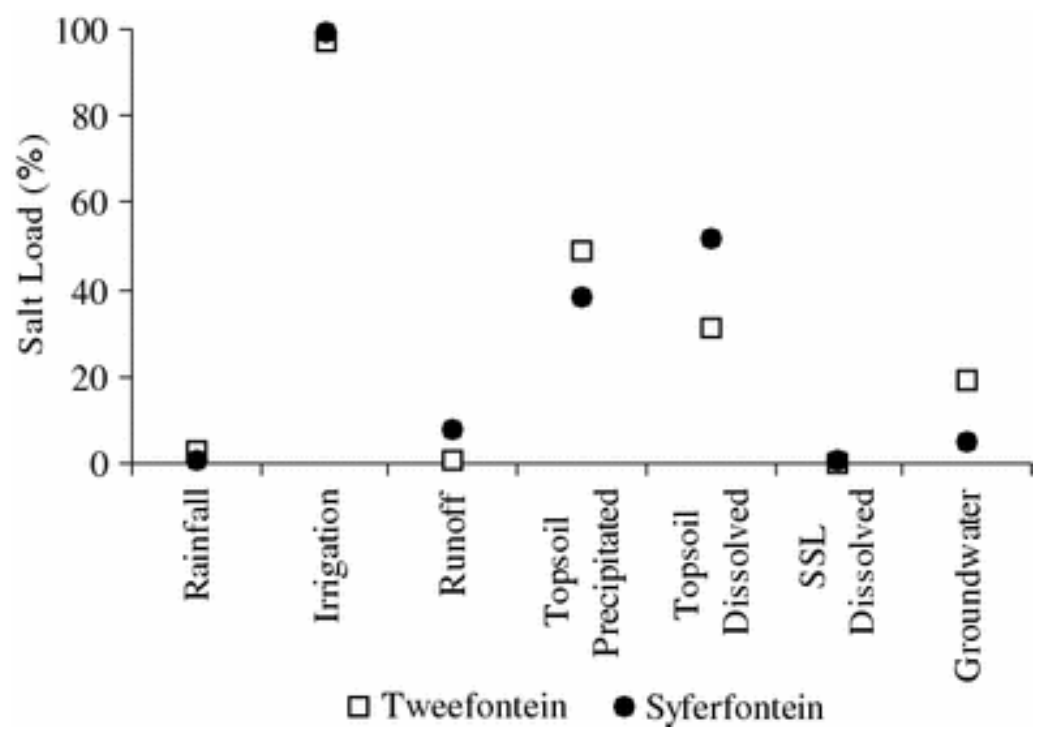

Fig. 8 Comparison of pivots Tweefontein and Syferfontein salt distribution 
The assessment of water and salts input onto both pivots Syferfontein and Tweefontein indicated that a significant part of the water input onto the pivots occurred as water evaporated from the soils and transpiration from plants, i.e. total evaporation. Total evaporation constituted not less than $75 \%$ at both pivots. Salts input onto both pivots were from rainfall and irrigation water. Irrigation water contributed almost all the salts, about 97 and $99.5 \%$ at pivots Tweefontein and Syferfontein, respectively. A significant proportion of the salts supplied to the pivots and generated within the system were either precipitated within the root zone or associated with the soil water in the topsoil (i.e. about $90 \mathrm{t}$ at Syferfontein and $80 \mathrm{t}$ at Tweefontein). The salt saturation values (representing the maximum subsurface soil water quality beyond which no salt generation takes place and at which precipitation of salts occurs) obtained for Tweefontein and Syferfontein were 5,000 and 3,500 mg/l, respectively. The different nature of soils at the pivots and different salinities of the irrigation water may be responsible for the difference in the salt saturation values. A comparison of the crop tolerance and yield potential of different crops as influenced by irrigation water and soil salinities (Ayers and Westcot 1994) with the salinities of the irrigation water used at the two pivots and the salt saturation values, indicate that many crops can be successfully irrigated at $100 \%$ yield potential, including barley, cotton, sugarbeet, sorghum, and wheat. The precipitation of salts in the soil horizons, however, means that salts could accumulate in the soil to damaging concentrations that could reduce crop yields, thereby making effective crop management and fertilization application imperative.

\section{Electrical Resistivity Survey}

The survey line at the pivot Syferfontein was about $700 \mathrm{~m}$ long. The pseudo-section of the 2-D model interpretation (to a depth of about $10 \mathrm{~m}$ ) along the line of investigation is shown in Fig. 9. The general range of resistivities of the subsurface soil materials (4.98$164 \Omega \mathrm{m}$ ) was indicative of unconsolidated or weathered materials with soil water or/and dissolved ions. The general increase in resistivities with depth and the lateral variation of resistivity values reflects the varying nature of the lithologies as well as the amount and quality of water in the subsurface of the pivot area. The lithologic profile consists of black clay, underlain by a dolerite dyke or sill, which in turn is underlain by yellowish clay. The dolerite is thoroughly weathered and fractured at the top. The black clay, which is the topmost layer in the pivot area, has the lowest resistivity and is generally less that $0.7 \mathrm{~m}$ in the southern half of the line of investigation (stations 0-340), whereas it appears much thicker in the northern half (stations 340-600), with a thickness of up to $6 \mathrm{~m}$ in some places. This may be the nature of the layer in the area, but may also reflect the salt distribution in the geoelectric layer, indicating that the salt associated with the mine water used for irrigation influenced the subsurface more in the direction of the surface and near surface flow of soil water, down the slope and towards the outlet of the pivot. The pivot slopes in the south-north direction and the survey line was actually close to the outlet through which the runoff was leaving the pivot area. 


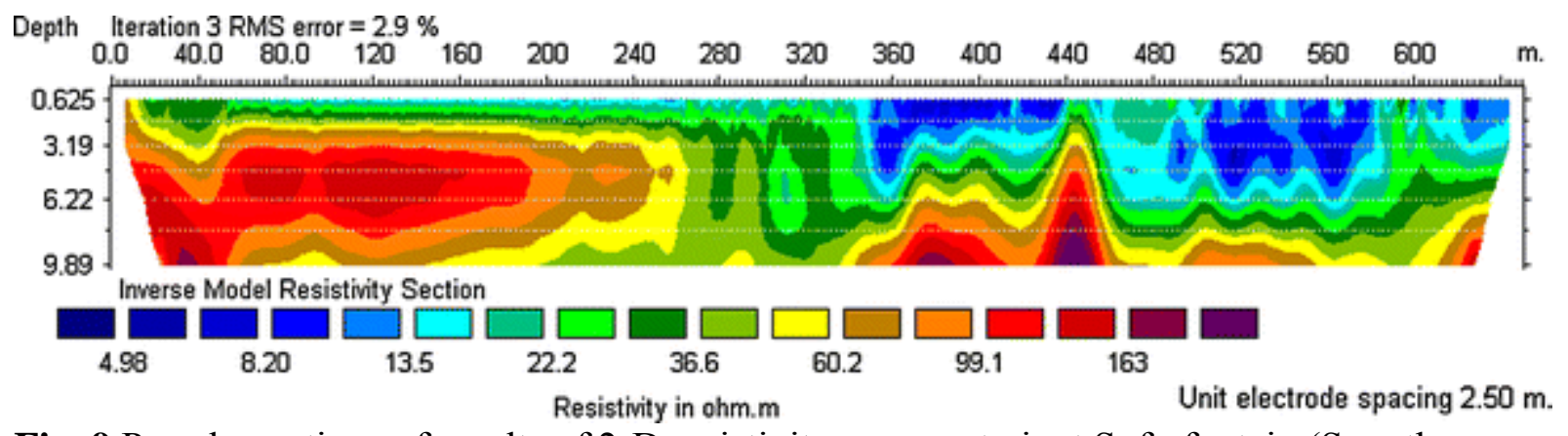

Fig. 9 Pseudo-sections of results of 2-D resistivity survey at pivot Syferfontein (S on the left)

In comparison to the apparent resistivity values for Syferfontein, which ranged from 4.98 to $164 \Omega \mathrm{m}$, the apparent resistivity values for Tweefontein range from 15.5 to $679 \Omega \mathrm{m}$ (Fig. 10), indicating a more resistive subsurface of the spoil underlying the topsoil used for rehabilitation. Similar to the situation at Syferfontein pivot, the pseudo-section of the 2-D model of the subsurface shows a general increase of resistivity with depth. At the beginning and end of the survey line, the subsurface resistivities were higher. These areas lay outside the pivot area irrigated with mine water; the lower resistivity values that occurred in the pivot area reflect the influence of the mine water used for irrigation. Similar to Syferfontein, the areas with the lowest resistivity values increased in thickness towards the outlet of the pivot area. The pseudo-section shows areas of contrasting and isolated resistivities, which reflect the variability in the size and composition of the spoil underlying the topsoil at Tweefontein. Cracks and voids in the topsoil and spoil, caused by settling and weathering of the spoil, allow irrigation water to percolate and cause areas of varying resistivities in the subsurface. The rehabilitated nature of pivot Tweefontein was reflected in the 2-D model of its subsurface, which contrasts sharply with that at another pivot (not shown), which was irrigated with mine water from the same mine but over unmined areas, and where resistivity consistently decreased with depth.

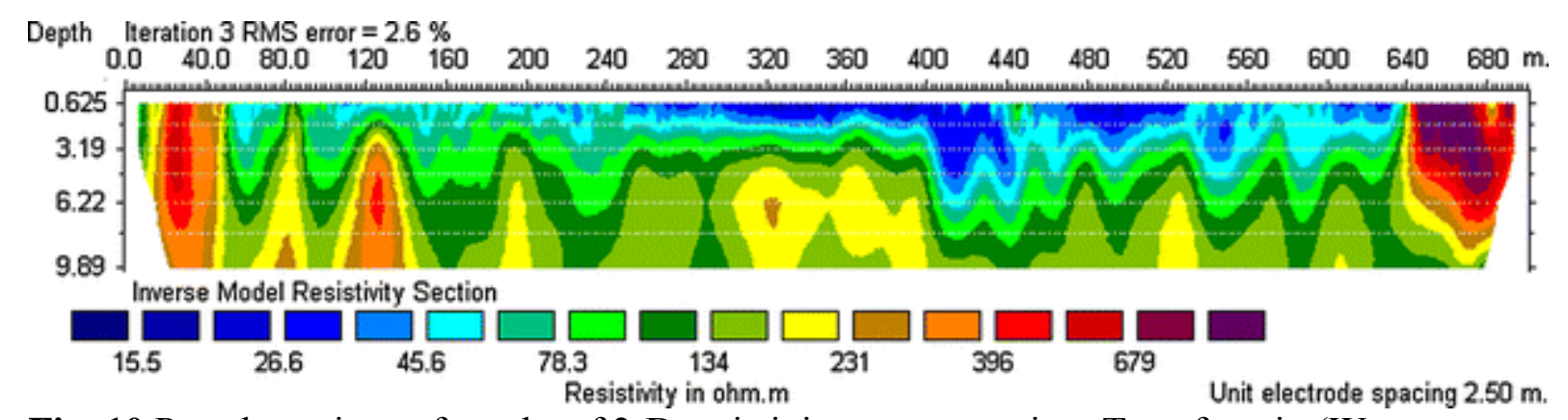

Fig. 10 Pseudosections of results of 2-D resistivity survey at pivot Tweefontein (W on the left) 


\section{Conclusion}

On both virgin and rehabilitated soils, a significant proportion of the salt input from rainfall and irrigation water will either be precipitated within the root zone in the soil horizons or associated with the soil water in the soil horizons. The volume of water and mass of salt export from an area irrigated with low quality mine water is controlled by whether the irrigated area is rehabilitated or unmined, as well as the soil type characterising the irrigated area. However, the kinds of response in a rehabilitated soil may be expected to vary depending on the kinds and methods of rehabilitation, e.g. the textural characteristics and depth of the topsoil overlying the spoils, the degree of spoil compaction before placement of topsoil, and the slope of the rehabilitated land. Our assessment of irrigation with mine water on virgin soils of clay and rehabilitated soils of sandy loam underlain by spoil indicated that less runoff occurred and more water drained beyond the root zone into the ground water in the rehabilitated soils. Similarly, a higher percentage of salts accompanied the runoff in the clayey virgin soils while more salts drained into the ground water storage in the rehabilitated soil. However, the salinities of the irrigation water used at the two pivots and the simulated salt saturation values indicate that many crops (such as barley, cotton, sugarbeet, sorghum, and wheat) can be successfully irrigated at $100 \%$ yield potential. The greater amount of water and dissolved salts supplied to the virgin and rehabilitated soils through irrigation apparently lowered soil resistivity values in the irrigated areas. The occurrence of a thicker, low-resistivity, near-surface layer near the exit of each pivot area indicated that the water and salt content of the subsurface increased in the direction that the surface and near-surface irrigation water flowed.

\section{References}

Annandale JG, Benade N, Jovanovic NZ, Steyn JM, Du Sautoy N (1999a) Facilitating irrigation scheduling by means of the soil-water balance model. WRC report No 753/1/99, Pretoria, $285 \mathrm{pp}$

Annandale JG, Jovanovic NZ, Benade N, Tanner PD (1999b) Modelling the long-term effect of irrigation water on soil and water resources. Agric Ecosyst Environ 76:109-119

Annandale JG, Jovanovic NZ, Pretorius JJB, Lorentz SA, Rethman NFG, Tanner PD (2001) Gypsiferous mine water use in irrigation on rehabilitated opencast mine land: crop production, soil water and salt balance. Ecol Eng 17:153-164

Annandale JG, Jovanovic NZ, Claassens AS, Benade N, Lorentz SA, Johnston MA, Tanner PD, Aken ME, Hodgson FDI (2002) The influence of irrigation with gypsiferous mine water on soil properties and drainage water. WRC report 858/1/02, Pretoria, $302 \mathrm{pp}$

Annandale JG, Jovanovic NZ, Hodgson FDI, Usher BH, Aken ME, van der Westhuizen AM, Bristow KL, Steyn JM (2006) Prediction of the environmental impact and 
sustainability of large-scale irrigation with gypsiferous mine-water on ground water resources. Water SA 32(1):21-28

Ayers RS, Westcot DW (1994) Water quality for agriculture. FAO Irrigation and Drainage Paper 29, Rome

Barnard RO, Rethman NFG, Annandale JG, Mentz W, Jovanovic NZ (1998) The screening of crop, pasture and wetland species for tolerance of polluted water originating in coal mines. WRC report No. 582/1/98, Pretoria, 337 pp

Beletse YG (2004) Modelling the soil water and salt balance of planted pastures irrigated with sodium sulphate rich mine effluent. Unpublished MSc Thesis, Natural and Agricultural Sciences, University of Pretoria, Pretoria, 137 pp

Blight JJ (1992) The influence of landfill covers on the generation of leachate. Unpublished MSc Dissert, University of Witwatersrand, Johannesburg

Clark DJ, Kiker GA, Schulze RE (2001) ACRU2000 structure and principles. Version 1.0, SBEEH, University of KwaZulu-Natal, Pietermaritzburg, 75 pp

Department of Water Affairs (2002) South Africa's water situation, and strategies to balance supply and demand. Proposed 1st Edition, National Water Resources Strategy, DWAF, RSA, pp 12-45

Du Plessis HM (1983) Using lime treated acid mine water for irrigation. Water Sci Technol 15:145-154

Ferguson RI, Trudgill ST, Ball J (1994) Mixing and uptake of solutes in catchments: model development. J Hydrol 159:223-233

Grobbelaar R, Usher B, Cruywagen LM, De Necker E, Hodgson FDI (2004) Long term impact of Intermine flow from Collieries in the Mpumalanga Area. WRC report No 1056/1/04, Pretoria, 116 pp

Idowu OA (2007) Impact of irrigation with gypsiferous mine water on the water resources of subcatchments in the Upper Olifants basin. PhD Thesis, SBEEH, University of KwaZulu-Natal, Pietermaritzburg, 254 pp

Jovanovic NZ, Barnard RO, Rethman NFG, Annandale JG (1998) Crops can be irrigated with lime-treated acid mine drainage. Water SA 24(2):113-122

Jovanovic NZ, Annandale JG, Claassens AS, Lorentz SA, Tanner PG, Aken ME, Hodgson FDI (2002) Commercial production of crops irrigated with gypsiferous mine water. Water SA 28:413-421 
Kenny A (2006) Energy supply in South Africa. In: Winkler H (Ed) Energy policies for sustainable development in South Africa. Energy Research Centre, University of Cape Town, Cape Town, pp 45-60

Lecler NL, Schulze RE (1995) Irrigation crop water demand. In: Schulze RE (Ed) Hydrology and agrohydrology: a Text to accompany the ACRU 3.00 agrohydrological modelling system. WRC, Pretoria. Report TT69/95:AT17-1-AT17-18

Limpitlaw D, Aken M, Lodewijks H, Viljoen J (2005) Post-mining rehabilitation, landuse and pollution at collieries in South Africa. Presented at Colloquium: sustainable development in the life of coal mining, Boksburg, $10 \mathrm{pp}$

Loke $\mathrm{MH}$ (2000) Electrical imaging for environmental and engineering studies, a practical guide to 2-D and 3-D surveys. Birmingham, $61 \mathrm{pp}$

Loke MH (2004) Tutorial: 2-D and 3-D electrical imaging surveys. Birmingham, 128 pp

Pearson KE (2003) Diagnosing salinity problems. Presented at the ASA-CSSA-SSSA annual meeting, Denver, 5 pp

Rhoades JD, Kandiah A, Marhali AM (1992) The use of saline water for crop production. FAO irrigation and drainage paper 48. FAO, Rome

Schulze RE, Angus GR, Lynch SD, Smithers JC (1995) ACRU: concepts and structure. In: Schulze RE (Ed) Hydrology and agrohydrology: a text to accompany the ACRU 3.00 agrohydrological modelling system. Water Research Commission, Pretoria, Report TT69/95:AT2-1-AT2-26

Sharpley AN, Ahuja LR, Yamamoto M, Menzel RG (1981) The kinetics of phosphorous desorption from soil. Soil Sci Soc Am J 45:493-496

Thornton-Dibb SLD, Clark DJ, Lorentz SA (2005) The addition of a soil surface layer and corresponding processes to ACRUSalinity. Report, SBEEH, University of KwaZuluNatal, Pietermaritzburg, $20 \mathrm{pp}$

Tweldebrhan AT, Lorentz SA, Schulze RE (2003) The hydrosalinity module of ACRU agrohydrological modelling system (ACRUSalinity) User Manual. ACRUcons Report 47, SBEEH, University of KwaZulu-Natal, Pietermaritzburg, 45 pp 